\title{
Exemplaria
}

Medieval, Early Modern, Theory

\section{Towards a Typology of Absence in Old Norse Literature}

\section{Richard Cole}

To cite this article: Richard Cole (2016) Towards a Typology of Absence in Old Norse Literature, Exemplaria, 28:2, 137-160, DOI: 10.1080/10412573.2016.1151201

To link to this article: http://dx.doi.org/10.1080/10412573.2016.1151201

巴nublished online: 27 Apr 2016.

Submit your article to this journal $\sqsubset$

Q View related articles $\square$

View Crossmark data ¿ 


\title{
Towards a Typology of Absence in Old Norse Literature
}

\author{
RICHARD COLE \\ Harvard University, USA
}

\begin{abstract}
This essay accepts Patrick Fuery's challenge to "get directly engaged in issues of typology" when considering absence. The powers of lost lovers, slain gods, and howling voids in Old Norse literature are anatomized according to the many phenomena denoted by the word "absence." Demonstrating several species and differing degrees of absence, the essay also shows how each is created by a particular mechanism, and each tends towards specific emotional consequences. Each species of typology is illustrated with examples taken from Old Norse literature; yet its various types may well be applied beyond such contexts.
\end{abstract}

KEYWORDS absence, Old Norse, Kormáks saga, Eyrbyggja saga, Snorra Edda, mythology, Gilles Deleuze.

On the edge of the known world, Ívar Bárðarson travels around the deserted wastes of the Greenland colony, wondering what became of the thousands of souls who once lived there. ${ }^{\mathrm{I}}$ On a moonlit night in an Icelandic dale, the monster slayer Grettir Ásmundarson wrestles with his fear of the dark, tormented by visions of creatures that - as far as any other mortal knows - aren't really there. In a dingy mead hall, shrouded in the mists of the pagan past, the warrior Sigurðr Fafnisbáni gulps down the óminnis öl, the "Ale of Forgetfulness." Soon it will be as though Brynhildr, the woman he loves so dearly, had never existed. The tale of Sigurðr's forgetting is itself found in its poetic form on the precipice of the so-called "Great Lacuna:" a gaping hole of eight leaves in the Codex Regius. Absence, like Óðinn himself, wanders all over the Old Norse world, spreading confusion and chaos as it goes.

Like Óðinn, absence manifests itself in many shapes, knows many disguises, operates by differing mechanisms and performs different functions. Patrick Fuery, whose book The Theory of Absence is a key intervention in absence studies, illustrates the many faces of absence by pointing out that it is insufficient to figure absence in terms of "zero-one and true-false sequences" (2). Absence can only be broadly categorized in 
opposition to presence as "that which is not here." It cannot be accurately defined as such. That status which we colloquially confer on many different phenomena with the term "absence" cannot always be explained as a stark opposite to presence. Consider, for example, the absence of the champion Bǫðvarr from King Hrólfr's court at Hleiðagarðr before Chapter 23 in Hrólfs saga Kraka. He has never been there, but the audience knows that he is somewhere else, on a trajectory towards the king, and that his arrival will be necessary for the narrative to progress. Surely this is a quite different phenomenon from Steingerðr's persistent absence in Kormáks saga. There the warrior-poet Kormákr, ${ }^{2}$ torn with regret for jilting his one true love, Steingerðr, is nonetheless fueled in everything he does by the alternately inspiring passion and tormenting ardor of his love for her. As Kormákr pillages on a viking raid or utters his final words, "Gerðr, strádauða verða" ("Steingerðr, I die a worthless death"; 302), his beloved is obviously nowhere to be seen. Indeed, if she had been present to Kormákr then neither event would have happened to him. ${ }^{3}$ Yet absence in the former case (Boðvarr is yet to be here) is the result of different mechanisms and produces different results from that in the latter case (Steingerðr was once there, she is now gone).

At this juncture it may be helpful to introduce some of the terms that will be used to anatomize absence and its production in Old Norse literature. Our first contention must be that far from being binary, absence is in fact relative. Steingerðr is absent compared to the sword, Skǫfnungr, in Kormákr's hand, or the men he fights alongside. But her absence is of a different order than this if we take Kormákr's mental horizon as our frame of reference. If she is constantly in his dreams and thoughts, she is surely less absent than something which is not in his thoughts at all. This proposition leads us to the question of subjectivity and distance. Absence has frequently been described as a subjective phenomenon (Fuery I2-I8, 74-80, Socor passim). That is to say, absence is the viewpoint of an observing subject towards an absent object.

For our purposes this subject can be variously configured as any given character in a saga, or indeed ourselves, the readers. The object can be anything (not) found in the text. Subject and object are here used in something like their grammatical sense, where the subject is the "the seer, the hearer, the feeler" and the object is "the seen, the heard, the felt." Between the observing subject and the observed object there is a certain distance. This distance can be literal, e.g., Steingerðr when she becomes estranged from Kormákr, or metaphorical, e.g., the "distance” between Sigurðr and Brynhildr after he has forgotten her. As we shall see, it is this distance which decides the degree to which the object can be considered absent.

The experience of absence as "not being (fully) here" naturally encompasses the state of "not here, but there." Again, we can observe the relativity of absence. Surely "not here, but there" can only be less absent than "neither here nor there." Consider this extract from Ari Porgilsson's Íslendingabók:

Í Pann tíð vas Ísland viði vaxit á fjalls ok fjǫru. Pá váru hér menn kristnir, Deir es Norðmenn kalla papa, en Deir fóru síðan á braut, af Dví at Peir vildu eigi vesa hér við heiðna menn, ok létu eptir bœkr írskar ok bjǫllur ok bagla; af Dví mátti skilja, at Deir váru menn írskir. (5) 
In those days Iceland was widely forested, from the mountains to the shore. There were Christians here then, those whom Scandinavians call papar, but then they went away because they did not want to be here alongside heathens, and they left behind them Irish books and croziers and vestments. From this we may discern that they were Irishmen.

What became of these papar? They conveniently forú sídan á braut (went then away), but as we don't know where exactly (back to Ireland perhaps? But who knows?), they might just as well have disappeared into thin air. Even though they once inhabited the Icelandic landscape, it follows that they are "more absent" from the world than, for example, the emigrant Gotlanders in Guta saga. After relating an episode in which a choosing of lots attempts to resolve Gotland's problems with overcrowding, the story notes that a third of the population were cast out: So bygPus Pair Par [Byzantium] firir ok enn byggia, ok enn hafa Pair sumt af varu mali ("So they settled there [Byzantium] and they still live there, and even now they have something of our language"; 4). The settlers have lost part of their identity, being no longer Gutnish; they have exited the narrative; they are "gone" from Gotland and its saga. But for the reader knowing where they are and what has become of them mitigates their absence in a manner quite unlike that of the papar. We will return to these examples and the different types of absence they highlight later, but for now we will continue to fortify our starting point: the heterogeneity and relativity of absence.

Both in modern English and Old Norse the word absence is etymologically derived not from "not-being," but from "being away." As The Oxford Dictionary of English Etymology notes, the English word comes from Latin $a b$, "away" and esse "being" (4). Similarly, Norse frávera is composed of frá, "away" and vera, "being." Indeed, the overwhelming attestation of this word in hagiographic works implies it may well originate as a calque of the Latin. Whether by accident or by design, the differentiation between not-being and being-away reflects the implicit impossibility of true and perfect absence. By speaking of absent things, by imagining them, or by touching them with any kind of sign-signifier system we violate that discredited "zero-false state" to which Fuery referred earlier. We have introduced just a little bit of presence into the mix.

"Not-being" is nonetheless a distinct phenomenon. There are things of which we do not know that have, will, or do exist — but to speak or even think of them violates their absence. This is because in speaking of them their presence to us is increased. Relative to things entirely unknown, we have a degree of intimacy with things absent but spoken. This problem is akin to "the observer's paradox:" one must observe a process in order to understand its mechanisms, but the presence of an observer perverts those mechanisms so the process viewed is different from the one the observer seeks to understand. The manner in which "not-being" is transformed by conscious perception demonstrates the principle of absence as subjective: absence is a phenomenon that exists in varying degrees depending on the distance at which conscious subjects perceive it. As Bille et al. put it: "What might appear as binary opposition between presence and absence is in fact often conceptualized within a continuous and ambiguous spectrum" (IO). 


\section{A Typology of Absence}

Bille et al. are right to highlight the ambiguity of presence and absence. Nonetheless, it is possible to detail a few points on the continuum between the two poles of presence and absence. Fuery notes that the "forms that [...] absences can take are considerably diverse," but stops short of anatomizing those forms, noting that as a philosopher it is not his to job to be "directly engaging in issues of typology" (I). Fuery observes two orders of absence, primary and secondary:

Secondary absences are those which are always derived from a state of presence. They imply presence, acknowledge its relational context, gain their epistemological and ontological structures from it, and indicate sites of presence. They retain, and even reinforce, the binarism of presence and absence. Primary absences, on the other hand, exist outside of any relational context of presence. Primary absences exist in their own right, independent of any sense of presence. $(\mathrm{I}-2)$

Fuery's schema is perfectly coherent, but it can be adapted on two points in an Old Norse context (or indeed any other narrative environment).

First, it must be made clear that while most of the species of absence which will be outlined shortly do not indeed exist "independent of any sense of presence," they should not be seen as dependent on presence in the manner of a linguistic binary pair: absence is not just the opposite or lack of presence, but is a phenomenon in its own right. In Kormáks saga, for instance, the narrative voice does not prompt a reading powered by a “will he/won't he get the girl” dynamic. After Chapter I I in that saga, it is obvious that the Kormákr and Steingerðr will never again be lovers. There is no plausible trajectory towards presence here — as Einar Ól. Sveinsson (I8) noted, "[the] subject is [...] the poet and the woman who walks by." We, the audience, are not actually waiting for Steingerðr to reappear and couple with Kormákr (we might wonder to what extent Kormákr himself is really waiting for that either). Instead, the focus is on the anguish and madness which Steingerðr's absence itself inflicts on Kormákr. In Old Norse literature, absence may well approach (or indeed speed away) without going hand-in-hand with presence.

Second, while Fuery's philosophical concerns call for just two orders of absence, as readers of literature we are very much required to "engage in issues of typology" which the philosopher avoids. Our continuum of absence allows us to discern at least six distinct points, each with its own mechanisms of action and phenomenological implications.

\section{i) Never-here-never-there (Perfect absence)}

To all intents and purposes, such absolute absence is synonymous with Fuery's "primary absence." Like the mathematician's "little i” or better yet Donald Rumsfeld's "unknown unknowns" it can only exist hypothetically. We cannot imagine a thing that possesses this state. We may only describe the state itself, because even imaginary objects possess a definite distance from the subject. We might say that thorium reactors, laser pistols, square circles, or eight-legged men enjoy such a status in the world of the sagas (and in our world too for that matter), but to do so would be slightly misleading. As previously 
iterated, the act of imagining establishes a subject-object / observer-observed / signifier-signified relationship. We cannot say such things are never-here-never-there, because they exist in the there of our thoughts or speech.

Nonetheless, such theoretical absence is important because it is from this dark place where we cannot look that all absence and presence alike must ultimately come. Indeed, Old Norse literature has really beaten us to it in describing such a virgin void. Consider the version of Voluspá attested in Snorri Sturluson's Edda:

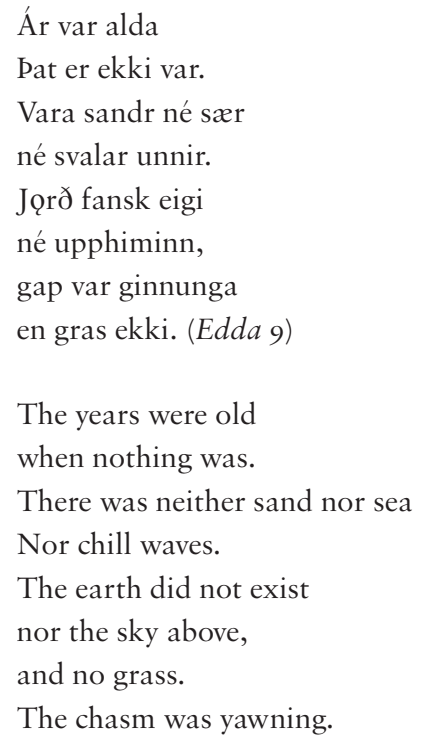

Eager to scrub out every last vestige of presence, the sibyl attempts to create a space without a subject, and thus a place where there can be none of the marked distance between subject-object that characterizes absence. The second line of Snorri's stanza - Dat er ekkivar - is found only in his Edda, not in the versions of Voluspá preserved in the Codex Regius, Hauksbók or the Codex Upsaliensis. In Old Norse myth the Ginnungagap — "Yawning Void" — is a space before creation. Like our Perfect Absence, it is from here that all things present or absent must come. It is a place devoid of observers, and so it exists before the absence-tainting act of signification. If the version of Voluspá which Snorri uses is from either his own modification of the poem or results from his deliberate curation of a now lost tradition, then it is safe to connote that Snorri was aware of the power of the Ginnungagap as a field in which absence can operate. He chose his words when he urged the reader to consider a universe "where nothing was."

\section{ii) Never-here-now-there}

We must take care to note that "now here" and "now there" do not carry with them connotations of relative time. When discussing absence, "now there" ought not to designate "recently appeared there" or "recently realised there" (e.g., this unhelpful sense of "now" is used by Bishop Árni Porláksson, who when touched by his clerk's words as he believes 


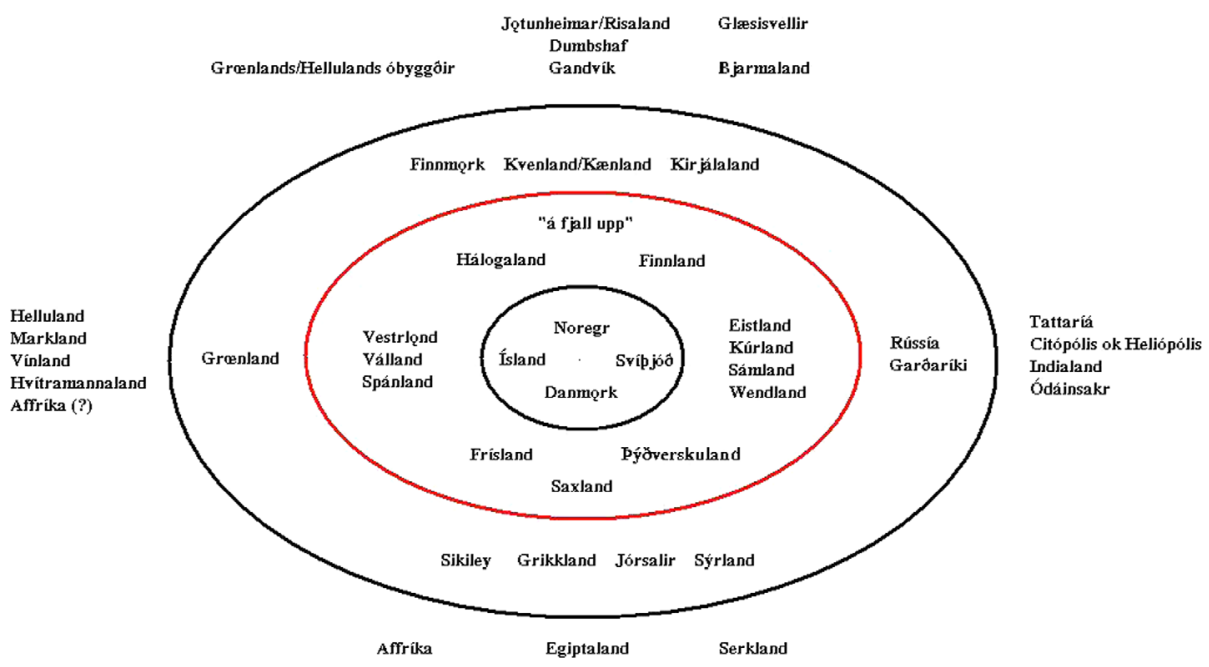

FIGURE 1 Concentric circles of familiarity centred on Scandinavia (Shafer 8).

himself to be mortally ill, says "Nú it fyrsta sinn sé ek at Pér elskit mik"; Árna saga 53). Árni uses nú (now) because a few moments earlier this point had been unknown to him. When discussing absence, "now there" designations should speak only for the present moment. We should consider things of the "never-here-now-there" category irrespective of whether they have just arrived or might be just about to leave; we should instead only reckon their current distance from the subject. This is the same usage of "now" we find in a lausavisa by Kormákr: Hvar's nú baugr enn brenndi? ("Where is my beautiful woman now?”; 288).4 Like a true student of absence, Kormákr desires to know a position as it stands, outside of its relationship to other times and states. The project of categorizing a state of affairs as a particular type of absence begins with examining a still photograph of a whirling universe.

Ethnic others in Old Norse literature have a particular propensity towards the state of never-here-now-there. Consider, for example, John Shafer's diagram (Figure I) of the "mental map" of a thirteenth-century Old Norse-speaker. Taking a synoptic view of Old Norse literature, we might note that all the weird and wonderful racial archetypes are to be found outside the innermost circle of places (Ísland, Noregr, Svípjó ð, Danmork). The martial Serkir — or Saracens - belong primarily in the areas we would now identify as the Islamic world (Affrika, Egiptaland, Serkland, Jórsalaland, etc.). The Blámenn - Black Men - at times berserkir, at times outright demons, belong in Affrika, Bláland, and alongside wherever one might find Serkir. The treacherous Gyðingar might be found in Spain / Spánland, Germany / Pýðverzkuland or England 5 - indeed, anywhere in Christendom outside of Scandinavia (Cole, "The Jew" I37-74). On the frozen fringes of the known world, the skraelingar of Greenland, svartir menn ok illiligir ok hofðu illt hár á hofði (dark, ugly looking men with ugly hair on their heads; Eiriks saga 227), pepper the Icelandic colonists with arrows, and attack with a fiendish war machine. We might well imagine that for a medieval Icelander, meeting with these colorful characters on the page was 
an exhilarating, perhaps even terrifying, experience. But it is not just their racial exoticism that would have made it so. It is also their absence. They are there. We, the Icelanders, are here. We can imagine them, reinvent, re-read them again and again. The blámaðr is a perfect example of this tendency, being by turns a king's champion, a berserker, and a demon (Fritzner I49-I50; Cole "Racial Thinking"). Yet even so, they must always be away. They may not come here. They are what lies beyond here and now. ${ }^{6}$

Inhabiting the first observable degree of absence, things of this category tend to be unstable, and soon move to another stage of coming or going. Certainly, if we dig a little deeper beyond our synoptic analysis, we find a few troublemakers violating the sanctity of that inner circle where the Scandinavian subject resides. A scribal error in Góttskálks Annall means that in the year 1232 tyndis gydinga skip $j$ Orkneyum ("a ship of Jews was lost off the coast of Orkney"; 327). (Orkney was at the time, of course, a part of Norway.) The skreelingar also transgress the borders of Scandinavia, when Karlsefni in Eiríks saga Rauða captures two Inuit boys on his way back from Markland [ok] kenndu Peim mál, ok váru skirðir ("and taught them to speak, and had them baptised"; 233). Snorri gets in on the act too, connecting Sweden with Serkland and populating it with blámenn:

Svípjóð ina miklu kalla sumir menn eigi minni en Serkland it mikla, sumir jafna henni við Bláland it mikla. Inn nørðri hlutr Svípjóðar liggr óbyggðr af frosti ok kulda, svá sem inn syðri hlutr Blálands er auðr af sólbruna. I Svípjóð eru stórheruð mǫrg. Par eru ok margs konar pjóðir ok margar tungur. Par eru risar, ok par eru dvergar, par eru blámenn, ok par eru margs konar undarligar pjóðir. (Ynglinga saga 9-10)

Some people call Greater Sweden [Scythia] nothing less than Greater Serkland. Some equate it with Greater Bláland. The northern part of Sweden lies uninhabited because of the ice and cold, just as the southern part of Bláland does because of the burning of the sun. In Sweden there are many administrative districts. There are also many kinds of ethnic groups and many languages. There are giants and dwarves. There are Black Men, and there are many kinds of weird ethnicities.

Nonetheless, the instability of the never-here-now-there position is visible only with hindsight. In the current moment, staring into that metaphorical static photograph mentioned earlier, it can be utterly compelling and seductive. Consider how it must have felt to be a Medieval Icelander, hearing of the terrible misdeeds of the Jews in Maríu saga. As in the phenomenon of "white flight," in a town where ethnic minorities are conspicuous by their absence and the residents continually congratulate each other on how "clean and quiet" it all is, Iceland's ethnic homogeneity becomes a great comfort, the rolling dales and glacial plains become (un)populated by absent enemies.

\section{iii) Once-here-now-gone}

Until now all the absent states considered have been passive configurations. These allude to the case in which the subject has no control over things present elsewhere but beyond the grasp of the subject. Whether as observers of reality or readers of literature, we do not decide the layout of the scenes we see. If something is missing, so be it. If something 
unpleasant glares us in the face, just the same. Here is a new case: to erase something or to put it at an unknowable distance from ourselves - is the first stage of an absence created actively rather than surveyed passively. We have already seen this to some extent in the case of the papar. Ari Porgilsson simply writes the native population of Iceland away. The Gotlanders are moved - placed over there. The papar are gone.

It is hard to create this kind of absence without giving off the air of an act of malice. This is because a thing can only be rendered gone either by annihilation (death, destruction, the forgetting of the óminnis öl, etc.), or by casting it away into such a state of doubt that we can no longer imagine its environs or context. This is a state so obscure that it no longer meets the demands of the subject's knowledge in order to be deemed there, like Gillingr's body, lost at sea. Once made absent in this way, however, the vestiges of things cleansed do more than just remind us of the awesome distance placed between subject and object. Bille et al. briefly discuss this dynamic when citing the work of James E. Young, who describes his response to a Holocaust memorial:

"Armless sleeves, eyeless lenses, headless caps, footless shoes: victims are known only by their absence, by the moment of their destruction. In great loose piles, these remnants remind us not of the lives that once animated them, so much as of the brokenness of lives" (Young I32-33). In this sense, the memorial invokes a simultaneous distance and proximity of the Holocaust, whereby the internalisation of presence, as being-in-touch, unfolds as more than mere spatial proximity and equally as more than a cognitive capacity to construct meaning and recollection. (Bille et al. 9)

This kind of absence mutates the function of the object. Young's response to the memorial evokes feelings beyond not seeing merely "people who are gone:" Indeed, he cannot see "people" at all. He sees victims. He experiences the process of "making absent." Moreover, it is not only from the vantage of the observer that this process is unavoidably imbued with transformative power. It is the same for the perpetrator. Although the facts are a bit murky, Hannah Arendt and others report what is probably a mostly accurate story: had the Nazis succeeded in eradicating the Jews in Europe, they would have set up a "Museum of The Extinct Race" in Prague (Arendt 37). While they were here, the Jews were viewed as a racial enemy to be destroyed without mercy. Once gone, they could become a thing of wonder, beheld in their own dedicated museum.

Naturally, we cannot easily compare the massive, factual, tragic events of the Holocaust with the minor, textual events of the Icelandic Íslendingabók and Landnámabók or the Norwegian Historia Norwegie. Nonetheless, there is a marked parallelism in the structural function of absence here. As we have seen, Ari perhaps rather euphemistically says of the indigenous papar that, "vildu eigi vesa hér við heiðna menn" (they did not want to be here alongside heathens; 5 ). The Historia Norwegie, while not Old Norse literature per se, gives a fuller account of what happened to the Papar in Orkney:

Istas insulas primitus Peti et Pape inhabitabant [...] Pape uero propter albas, quibus ut clerici induebantur, uocati sunt, unde in Theutonica lingua omnes clerici 'pape' dicuntur. Adhuc quedam insula Papey ab illis denominatur. Sed ut per habitum et apices librorum euorum ibidem derelictorum notatur, Affricani fuerunt iudaismo adherentes. Istas itaque naciones 
in diebus Haraldi Comati, regis uidelicet Norwegie, quidam pirate, prosapia robustissimi principis Rogwaldi progresso, cum magna classe Solundicum Mare transfretantes de diuturnis sedibus exutas ex toto deluerunt ac insulas sibi subdiderunt.

Originally those islands were inhabited by Pents and Papes $[\ldots]$ The Papes were so called on account of the vestments in which they closed themselves like priests, and for this reason all priests are known as papen in the German tongue. One of the islands is still named Papey from them. However, as the appearance and letter-forms of the books they left there behind them testify, they were from Africa and clove to the Jewish faith. In the days of Harald Fairhair, king of Norway, [...] crossing the Solund sea with a large fleet, totally destroyed these peoples after stripping of them of their long established dwellings and made the islands subject to themselves. $(65-67)$

And once the violence is done, the Norsemen sit down to examine the "boekr irskar, bjollur ok baglar ok enn fleiri hlutir" (Irish books, croziers, vestments and other articles; Landnámabók 32). They name features of the landscape after the very people that they cleansed from it. 7 The Scandinavians perusing the unreadable books, bodiless vestments, and unwielded croziers are in spirit not entirely unlike the Nazis planning to fill up their museum with the kind of artifacts described by Young. Absence has transformed the papar from targets for ethnic cleansing into appropriate objects for memorialization. Moreover - and most weirdly — it has turned the killers of the papar into their admirers. Perhaps it is necessary that this kind of absence always results in some degree of grief, even in those who bring it about.

\section{iv) Once-here-now-there}

In Chapter I9 of Kormáks saga, the eponymous hero and his brother Porgils find themselves in the service of King Haraldr Greycloak (r. 96I-970), doing battle against the Irish. As a vast tumult of enemy soldiers descend on the king's guard, Kormákr does what he does best and composes a moving verse in honor of his beloved Steingerðr. It is at this point that Porgils turns to his brother and distils, in two deft lines, the essence of Kormáks saga:

Porgils mælti: “aldri kemr pú í pá mannraun at pér komi eigi jamnan í hug Steingerðr.”

Kormakr segir: "allítt fyrnisk mér pat enn.” (268)

Porgils said "you never risk your life without thinking of Steingerðr"

Kormákr says: "My memories still haven’t faded at all.”

For Kormákr, absence has become a kind of fuel, something that burns within him, propelling him with ever greater velocity towards his undoing. Indeed, Roland Barthes could have been describing this tenth-century Icelandic poet when he writes in A Lover's Discourse: "Absence persists - I must endure it. Hence I will manipulate it: transform the distortion of time into oscillation, produce rhythm, make an entrance onto the state of language [...] Absence becomes an active practice, a business" (I6; Fuery 4I-42). Steingerðr has not been obliterated. Once she was "here” to Kormákr as an observing subject: "Svá kveðk snyrti-Freyju, / snimr trúða ek brúði, / gamðis vangs of gengna / 
greipar báls ór sk3lom" ("So, I speak of how my woman / has gone like a hawk from / the hands that once grasped her fire"; Kormáks saga 23I). Now she is "there" with Bersi, and later Porvaldr. The potent volatility of absence as fuel stems from its particular state: she was once-here-now-there. It is not just that Kormákr cannot have what he wants. He can constantly imagine someone else having it.

In the case of Steingerðr we see someone being rendered absent because they are taken (at least, that's certainly how Kormákr sees it: "Brott hefr Bersi setta / .. heitkonu mina" ("Bersi has spirited away the woman promised to me"; Kormáks saga 228). Porgils is, as ever, more sober: "Getr pú hennar nú jafnan, en pá vildir eigi fá hennar er buðusk kostir á" ("You're always bringing her up, but you didn't want her when the opportunity presented itself"; 267). This leads to a situation characterized by the pervasive effect of desire. We might bring up any number of examples from Norse romances to illustrate that this particular configuration of absence is a state saturated in longing. In Tristrams saga ok Ísondar, to name but one, the titular hero employs a number of strategies for coping with the absence of his beloved. Most strikingly perhaps, he creates statues of his absent lover, Ísond, her handmaiden, Bringvet, and even her pet dog. ${ }^{8}$ These statues are so passionately intended to mimic animate beings that they might better be described as robots:

Tristram hafði gert undir geirvörtunni jafnsítt hjartanu eina boru á brjóstinu ok setti Par einn buðk, fullan af gullmölnum grösum, peim sætustum. er í váru öllum heiminum. Ór Pessum buðk stóðu tveir reystafor af brendu gulli. Ok annarr Pessara skaut ilm út undan hnakkanum, Par sem mættiz hárit ok holdit, en annarr með sama hætti horfði til munnsins. Dessi líkneskja var at sköpun, atgerð ok mikilleik svá lík Ísönd dróttningnu, svá sem hún væri Par sjálf standandi, ok svá kviklig sem lifandi væri. [...] Ok jafnan sem hann kom inn til líkneskju Ísöndar, Pá kyssti hann hana, svá opt sem hann kom, ok lagði hana í fang sér ok hendr um háls, sem hún væri lifandi, ok ræddi til hennar mörgum ástligum orðum um ástarPokka Peira ok harma. (I86-88)

Tristram had made a hole in the chest, just below the nipple where the heart would be, and placed a box inside filled with gold dust and herbs, the sweetest in all the world. Two straws of pure gold came out of this box. And one of these came out on the back of the neck, where the hair met the shoulders, from whence it sprayed the scent. And the other in the same way connected to the mouth. In shape, beauty and size this statue was so like Queen Ísönd that it was as though she were standing there herself, as animate as though she were alive [...] And whenever he came to the statue of Ísönd he kissed her as often as he could, and embraced her and took her in his arms as though she were alive, and spoke many loving words to her about their love and their grief.

Following conventions from the courtly love tradition, the narrator does not see Tristram's actions as piteous in any way. Indeed, when Tristram introduces his brother-in-law Kardín to the statue of Bringvet, Kardín is also love-struck, and the two men take up the habit of regularly visiting the cave to canoodle with their respective gynoid lovers. ${ }^{9}$ Filling the void left by someone once-here-now-there by the best replacement under the circumstances does not seem to have been a deplorable strategy in Old Norse literature. Even in Laxdcela saga, Guðrún can't have the absentee Kjartan and so settles for his best friend, 
Bolli. The ensuing events may be bloody, but Bolli remains a very sympathetic character. We certainly don't get the impression that Guðrún and Kjartan would really be happier if they ditched their respective spouses and remarried. Guðrún's famous last words are perhaps not even the riddle they seem to be: "Peim var ek verst, er ek unna mest" "I was worst to the one I loved the most"; 228). If one agrees that Bolli was the most mistreated man, the meaning seems clear.

It is not only in romances that we find the state of once-here-now-there leaving traces of a yearning for a restored presence. Even in the case of the emigrant Gotlanders in Guta saga (a people rendered absent by expulsion), there is perhaps a hint of colonial longing for the spreading of ethnic roots: enn hafa pair sumt af varu mali ("even now they have something of our language"; 4). In his Edda, Snorri, whom we have already seen discussing things absent, injects the story of Baldr's death with precisely this kind of absence, via his "invention" (Abram, "Snorri's Invention" 22-3I) of the helreið. Under normal circumstances, a death would constitute a higher order of absence: once-herenow-gone. But in the world of the gods this is not so. For the Æsir, there is no doubt over the distance between themselves (the subjects) and the object, Baldr. Hel is a real place to which one can ride; and indeed one can even converse with its personified form. That's where Baldr must stay. When Hermóðr is dispatched to beg for Baldr's release, he uses the same language of establishing spatial proximity with which we have been anatomizing absence:

Móðguðr er nefnd mær sú er gætir brúarinnar. Hon spurði hann [Hermóð] at nafni eða ætt ok sagði at hinn fyrra dag riðu um brúna fimm fylki dauðra manna,

“"En eigi dynr brúin minnr undir einum pér ok eigi hefir pú lit dauðra manna. Hví ríðr pú hér á Helveg?”

Hann svarar at "ek skal ríða til Heljar at leita Baldrs. Eða hvárt hefir pú nakkvat sét Baldr á Helvegi?”

En hon sagði at Baldr hafði par riðit um Gjallar brú, “en niðr ok norðr liggr Helvegr.”

Pá reið Hermóðr par til er hann kom at Helgrindum. (Edda 47)

The name of the maiden who guards the bridge is Móðguðr. She asked [Hermóðr] his name and lineage, and said that the day previous five troops of dead men had ridden over the bridge, "But the bridge makes no less noise under just the one of you, and you don't have the colour of dead men. Why are you riding the Path to Hel?"

He replies, "I am riding to Hel to look for Baldr. Perhaps you have seen Baldr on the Path to Hel?”

And she said that Baldr had ridden there over the Bridge of Gjoll, "but the Path to Hel lies downwards to the north."

Then Hermóðr rode there until he arrived at the Gates of Hell.

Snorri's clear situation of Hel as a known space provides a further barb to the grief of the gods. As Pórr kicked the dwarf Litr onto Baldr's funeral pyre, Baldr's wife sprakk af harmi ... ok dó ("collapsed with grief ... and died"; 46). The gods know where Baldr is 
and what he is going through. This is what the recognition of his absence at the feasts of the gods will always signify. If he were properly gone (annihilated in the most literal sense, that is, made into nothingness), the grief of the gods would be a terminable process; it would be an adaptation to a new order of reality (cf. Mills 476-8I). Instead, it is Baldr's absence itself and not the according bereavement that becomes the issue. This is not a finite process of adaptation (i.e., a need to accommodate the fact that Baldr was once-here and is now-gone), but an infinite state of constant remembering. He is and will be once-here-now-there until Ragnarok, the end of the world. All these discourses of ongoing longing arise because a thing which is once-here-now-there will always leave a sense of lack, whether the object was taken, cast out, or exited by its own volition. As Fuery via Jacques Lacan reminds us, "desire is constructed as a lack" (I6). ${ }^{\text {Io }}$

We should also note that the proximity to presence has been increasing with each of the four species of absence detailed thus far. At the stage of never-here-now-there the subject has the least possible degree of knowledge of the object. At the point of once-here-nowgone the subject has had direct experience of the object, but further interaction is now impossible. The object has no distance from the subject because it has been destroyed. Here the object does not necessarily threaten to return. The potential for return surely increases the possible perception of presence, but potentiality is not always implied by this state. Rather, this type of absence narrows the distance between subject and object, thereby increasing a kind of presence.

\section{v) Becoming-absent}

So far we have spoken of static states of absence, even if those states have sometimes shown themselves to be rather unstable. My basic mode of interrogation has involved asking "where is the object now?" But even when the continuous flow of time is suspended, as in our static photograph, there are some things which can only be positioned with reference to their trajectory. For the Structuralists, arguably the greatest theoretical influence on literary criticism in Old Norse circles (Lönnroth 63-73; Clover and Lindow 279-284; Lindow et al.), the idea of liminality emerged as a category of crucial importance, particularly with regard to organizing taxonomies of states of being (see especially Schjødt 22-27). At the risk of oversimplifying, structuralist scholars of Old Norse construe liminality as a position of "neither-here-nor-there;" it derives its transgressive and transformative properties from that neither/ nor. But in the case of absence this model is insufficient. Something may well be simultaneously absent in one regard, though present in another. Something may well fluctuate between these two poles. Is it then plausible to assign all such things to an indiscriminate category of liminality?

The draugr is a good example of this problem. Jürg Glauser describes the zombie-like figure of the drangr as "obscur[ing] the boundary separating life and death" (624). So far, so liminal. Yet, unlike the wispy, ethereal spirits found in other folklore, draugar are the bloated, blackened, decaying, aggressively present bodies of the deceased. During the daylight hours they disappear. Sometimes, as in the case of Killer-Hrapp in Laxdcela saga, they can be exhumed and exorcised. Elsewhere - Glámr in Grettis saga for example 
- they seem able to disappear into thin air. And if the body of the deceased is problematic, what are we to make of the mind? Ármann Jakobsson, describing his concept of "demonic contamination," notes that, "the ghost is very physical, his condition is transmittable [...] and his main function is to drain human bodies of their essence and their humanity" (3IO). Is someone who has died, or been killed, and become a draugr present or absent? Surely we cannot declare that he is still "here." At least not in the daytime. When a once harmless shepherd returns from the dead with a newly malevolent personality, is he once-here-now-gone or once-here-now-there? We can go further than simply marking the draugr as liminal. Rather, we need to talk about trajectories. Perhaps the draugr doesn't know whether he's coming or going. But we must.

Indeed, it is not only an evasion to speak of absence as a liminal state, it is also a tautology: every position we have outlined along the continuum of absence is between two poles, two perfect states. Thus, turning from the intellectual arsenal of the structuralists to that of the post-structuralists, I argue that we might abandon liminality in favor of becoming. Taking Lewis Carroll's Alice's Adventures in Wonderland as his starting point, Gilles Deleuze outlined becoming in this way:

Alice and Through the Looking-Glass involve a category of very special things: events, pure events. When I say "Alice becomes larger," I mean that she becomes larger than she was. By the same token, however, she becomes smaller than she is now. Certainly, she is not bigger and smaller at the same time. She is larger now; she was smaller before. But it is at the same moment that one becomes larger than one was and smaller than one becomes. This is the simultaneity of a becoming whose characteristic is to elude the present. (Logic of Sense 3)

Deleuze makes a forceful case for the impossibility of a mono-directional becoming. Consider his later statement: "“which way, which way?' asks Alice, sensing that it is always in both directions at the same time" (Logic of Sense 4). Speaking as a philosopher makes it easier for Deleuze to takes this position. His position as a reader is as flexible as the becoming he describes. He is investigating a reality of his own design, but readers of Old Norse literature are traveling through a reality crafted by others: namely, the writers of twelfth to fifteenth century Iceland and Norway. Deleuze moves his subject around. Alice can be smaller even as she gets bigger. This is because he can make his frame of reference be either a "now" (when Alice is at her biggest), or indeed a "then," when Alice was or will be smaller than she "is." He is investigating a reality of his own design. When we are being obedient readers of Old Norse literature we control neither our own subject position nor that of the characters in the text. We must follow the narrative voice.

The saga style, with its constantly shifting tenses, keeps a firm grasp on the temporal relationships between all parties in the text (reader, protagonist, antagonist, etc.). This may well be an unconscious stylistic choice on the part of the author, but we cannot deny the effect it has. Consider the temporal dynamics in the brief exchange between Kormákr and Porgils cited earlier. Porgils moelti, "said;" but Kormákr segir, "says.” The author makes it clear that it is for him to decide both the distance between Porgils and Kormákr, and indeed the distance between Kormákr and us, the reader. It is as though the saga author is dragging the reader around by the scruff of his neck: "look over here! 
Now, this happened. Now look over here! This is happening!” This is why if Deleuze had read a saga, he wouldn't be able to discover phenomena which "elude the present." Old Norse prose constantly rubs the present in our faces.

Thus, in the case of absence in Old Norse literature, the becoming of absence must be directional. As a general principle, it will be seen that the typical saga narrator always knows whether something in his tale is on a trajectory towards presence or absence, and seeks to impress this upon the audience. We can clearly discern two states where Deleuze would have noted one: becoming-absent and becoming-present. The draugar, then, belong to the former category. They are becoming-absent. As seen, they retain the flesh of their bodies, imbuing them with a startling sense of presence, particularly when compared to other revenants. ${ }^{\text {II }}$ Nonetheless, the draugar are "on their way out." Although they try to resist, they are on a trajectory towards being "gone." They have died. They may no longer demonstrate their presence during the day. Their personalities have been altered. Even the bodies to which they cling are decomposing and discoloured, often blár sem hel — "black as hell" (Cleasby and Vigfússon 254). They are waiting for something (such as a monster slayer like Grettir) to come and finally dispatch them. In the case of Eyrbyggja saga, they await due judicial process. Note the touching but ultimately vain longing on the part of the draugar to remain present:

... er dómsorði var á lokit um Póri viðlegg, stóð hann upp ok mælti: "Setit er nú, meðan sætt er.” Eptir Pat gekk hann út Pær dyrr, sem dómrinn var eigi fyrir settr. Pá var lokit dómsorði á sauðamann: en er hann heyrði Pat, stóð hann upp ok mælti: "Fara skal nú, ok hygg ek, at pó væri fyrr sœmra." En er Porgríma galdrakinn heyrði, at dómsorði var á hana lokit, stóð hon upp ok mælti: "Verit er nú, meðan vært er.” Síðan var sóttr hverr at ǫðrum, ok stóð hverr upp, sem dómr fell á, ok mæltu allir nǫkkut, er út gengu, ok fannsk Pat á hvers orðum, at nauðigr losnaði. Síðan var sókn felld á Pórodd bónda; ok er hann heyrði Pat, stóð hann upp ok mælti: "Fátt hygg ek hér friða, enda flýjum nú allir.” Gekk hann Pá út eptir Pat ... ok eptir Pat tókusk af allar aptrgęngur at Fróðá ok reimleikar ... (Eyrbyggja saga I 52)

... as judgement was passed on Pórir Pegleg, he stood up and said: "I sat here as long as I could." After that he walked out the doors, away from where the court had sat. Then judgement was passed on the shepherd. And when he heard it, he stood up and said "I'll go now, even though I think it's all too soon.” And when Porgríma the Witch heard that judgement had been passed on her, she stood up and said "I stayed as long as you let me." Then it came to each of them, and each stood up as judgement was passed, and they all said something as they left, and it was clear from their words that they did not want to go. Then sentence was passed on Póroddr the Farmer, and when he heard that, he stood up and said "I think I will get little peace here. We will all leave now". At that, he walked out ... and afterwards all the weird happenings and revenants at Fróðá ceased ...

The question that we must consider now is this: does the state of becoming-absent preclude a simultaneous inhabitation of another state? Are the draugar of Fróda, for example, becoming-absent and once-here-now-gone, or are they purely of the former position? It is neither unnecessarily flippant nor an admission of defeat to reply "we don't know." A Structuralist taxonomy of absence (or indeed a Structuralist taxonomy of anything else) demands an omniscient subject. A thing is X, Y, or liminal. It is a way 
of thinking which permits "shades of gray" but does not allow for doubt. But, following Fuery, our model of absence thrives upon doubt. Doubt is not a blight which obscures the truth or confounds our theoretical model: doubt is a reality. Sometimes the subject simply does not know the distance between himself and the object. As seen, this is one of the ways that something can end up "gone." Becoming-absent or becoming-present means we do not know our true relationship to the absent object. The ghosts of Fróða are governed by certaun unknown (meta)physical laws. Maybe they go somewhere during the day - under the sea perhaps? Or maybe they disappear to another plane of existence? But the saga author does not tell us this. Again, in stark contrast to Deleuze's experience reading Lewis Carroll, our narrator is "calling the shots." For an explicit declaration of this ideology of authorial dominance, consider the stern dressing down the reader gets from the author at the beginning of Gongu-Hrólfs saga:

\footnotetext{
Nú verðr hvórki Detta né annat gert eftir allra hugDokka, Dví at enginn Parf trúnað á slíkt at leggja, meir enn fallit Dykir; er Pat ok bezt ok fróðlegast at hlýða meðan frá er sagt, ok gera sér heldr gleði af enn angr, Dví jafnan er Pat, at menn hugsa eigi aðra syndsamlega hluti, á meðan hann gleðist af skemtaninni; stendr Pat ok eigi vel Peim, er hjá eru, at lasta, Pó at ófróðlega eðr ómjúklega sé orðum um farit, Dví fátt verðr full-vandlega gert, Dat er eigi ligger meira við enn um slíka hluti. (I45-46)

Since neither this nor anything else will be to everyone's tastes (because no-one can be made to put any more trust in these things than suits them) the best and cleverest thing to do is listen while it's being told, and try to have a good time rather than getting upset, because it's always the case that people never think of other sinful thoughts while they are being entertained and having a good time. It is also not good for those present to criticise the story, even if it is foolish or the words are not very well put together, because nothing is done perfectly even in matters more important than such story-telling.
}

We have been made passive (though cf. O’Connor IOI-69). Sit down, enjoy the story, stop thinking those "sinful thoughts"! Under the saga's reading regime it is not possible for us as reader-subjects to judge the distance between "here," "there," and "gone" any more than it is for the character-subjects to do so. (Though luckily, an insubordinate critical reader can still refuse to submit to this regime altogether.) The tyranny of the saga author means that we do not know whether becoming-absent is an exclusive state, and the state is not made less plausible or tangible by this doubt. Doubt defines this state.

\section{vi) Becoming-present}

In Eyrbyggja saga we also find a convenient example of becoming-present. We must concede to Deleuze that this state is indeed a kind of absence. Just as Alice is bigger than she was, not being biggest means she is smaller than biggest. By the same token, that which is becoming-present is still absent until it reaches its zenith. Just as the becoming-absent zombies of the saga vainly resist being banished to absence, that which is becoming-present seems to burn with desire for presence. The ghost in the following scene is doubtless a kind of aptrganga (revenant, literally "again comer"), perhaps the spectral reappearance of Pórgunna the Hebridean, because it pointedly trains its gaze on 
Pórgunna's bed clothes which she had asked to be burned after her death but which had instead been kept by Puríðr. The ghost takes the form of a seal, a familiar trope in the Íslendingasögur, but unlike other seal ghosts, it takes the novel step not of approaching by sea, but by (or through) land:

... ok er menn kómu fram, sá Peir, at selshǫfuð kom upp ór eldgrófinni. Heimakona ein kom fyrst fram ok sá Pessi tíðendi; hon tók lurk einn er lá í durunum, ok laust í hǫfuð selnum; hann gekk upp við hogggit ok gægðisk upp á ársalinn Pórgunnu. Pá gekk til húskarl ok barði selinn; gekk hann upp við hvert họgg, Par til at hann kom upp yfir hreifana, Pá fell húskarl í óvit; urðu Pá allir óttafullir, Peir er við váru. Pá hljóp til sveinninn Kjartan ok tók upp mikla járndrepsleggju ok laust í hǫfuð selnum, ok varð Pat họgg mikit, en hann skók họfuðit ok litaðisk um; lét Kjartan Pá fara hvert at ǫðru, en selrinn gekk Pá niðr við, sem hann ræki hæl; hann barði Par til, at selrinn gekk svá niðr, at hann lamði saman gólfit fyrir ofan hǫfuð honum. (I47)

... and as people approached, they saw a seal's head coming up out of the kitchen floor. A certain housewife was the first to go up to it and see this event. She took a cudgel which had been lying in the doorway and hit the seal on the head. At the blow it rose up, and peered curiously at Pórgunna's bed clothes. Then one of the men of the house went over and started beating the seal. It rose up with every blow until it was up to its flippers, then suddenly the man collapsed. At this point everyone who was there was terrified. Then the young Kjartan ran up to it with an iron sledge hammer and hit the seal on the head, and the blow was so great that the seal shook its head and looked around dazed. Now Kjartan didn't hold back, and the seal went down as though he were hammering a nail. He kept thrashing it until the seal was gone, and then he beat down the floor over its head.

At first glance, perhaps, the seal would appear to have no qualities of absence at all. It is very much here, scaring the household witless. But on closer inspection the seal begins to seem troublingly incomplete. Indeed, we find the same kind of doubt over the physical laws governing the seal that we saw with the draugar who were becoming-absent. Above ground level, it is very much tangible. Again in contrast to the wispy, ectoplasmic spectres of modern Anglophone folklore, it has solid flesh against which the blows of the húskarl connect. Yet what physical state does it have below the floor? There is no indication here that it is burrowing towards the surface; that would imply it has a solid, complete, present body from the outset. Instead it is simply said to ganga upp (go up). Thus we must adduce that it is literally materializing - acquiring matter before the horrified eyes of the people of Eyr. It isn't here yet, but it wants to be.

Indeed, just as the people of Eyr unite to drive out the becoming-absent drangar, they rush to repel the becoming-present selshofuð. I would contend that a vain effort to fortify the binarism of presence-absence is the result of all such hostile reactions to becoming-present phenomena, (although hostile reactionaries to newcomers would almost certainly not frame their reaction in the kind of theoretical language used in this article). We can observe the same reactionary response on behalf of the pagan resistance in Old Norse conversion narratives, from Kristni saga to the various sagas of Óláfr Tryggvason. Christianity, the becoming-present newcomer to Scandinavia, does not appear suddenly, with one irresistible and compelling miracle. Rather, the miracles 
slowly accrue, the heathen leaders are vanquished one by one - God Himself becomes present. We cannot say exactly when He appears (has He always been omnipresent? Is He the cause of the "noble heathen" archetype? Is He fully present with the first missionary? The first miracle? The defeat of the last pagan?, etc.). Doubt and distance become a theatre for the struggle between absence and presence. As Fowles reminds us: "it is in those moments when something has been actively rejected and aggressively avoided that we become especially aware of the flickering nature of absence and presence" (38).

\section{vii) Here (Perfect presence)}

Naturally, this is not a species of absence, but as a necessary ingredient in our typological spectrum, it warrants a few brief remarks. Hans Ulrich Gumbrecht has outlined what he calls "the production of real presence" (34) in a medieval, non-eucharist-sceptic mind. His broad survey of Western metaphysics in Production of Presence includes fine-detail study on the Eucharist, described by Gumbrecht as "the core ritual of medieval culture" (28). Gumbrecht argues that prior to the Reformation "those who wanted to think the relationship of humans to their world" (28) looked to a paradigm of unambiguous presence in order to do so. True, the Middle Ages produced magnificent works of figurative and allegorical thought (think of Amalar of Metz's Liber Officialis or William Durandus's Rationale Divinorum, both redacted in the Old Norse Messuskýringar) but divine presence, or presence as a metaphysical category, needed to be as solidly real as possible - hence the Aristotle-inspired deployment of substantia and accidens in the theory of transubstantiation. Gumbrecht situates this "real presence" in terms of propinquity to the "here and now" of the subject's body:

Medieval Christian culture was centered on the collective belief in the possibility of God's real presence among humans and in several rituals, most prominently the Mass, that were meant to constantly produce and renew such real presence. Presence, in this context, does not exclusively or perhaps even primarily pertain to the dimension of time but contains a claim of spatial proximity. We call "present" whatever at a given moment appears close enough to be in reach of our body and its touch. The Christian God's real presence, therefore, makes it possible to eat his body and to drink his blood [...] While medieval culture believed in the possibility of satisfying the desire for real presence by providing, over and over again, the certainty of God's real presence, our contemporary relationship to presence is an asymptotic one. We seem to feel that we constantly are in situations of either increasing or decreasing presence of the world without ever fully having that world present. (Philology II-I2; cf. Production 23-32)

Gumbrecht also deploys the method of investigating an epoch by comparison with its successor. Highlighting the Reformation's insistence that the eucharist was a figurative commemoration draws into sharp relief the power with which medieval Christianity invested presence (29-30). I would take Gumbrecht's proposition to what seems to me to be its natural conclusion: that not only God and Christ's body needed "real presence," but the world did too. The medieval church did not call on its believers to demonstrate what we would now call "faith", that is to say, a virtuous suspension of disbelief. God's 
existence was a fact of life, and belief in his omnipresence was sustained not by blind trust but by evidence: the presence of the world itself. It is, then, little wonder that medieval culture apparently sponsored so few deconstructions of presence, such as the one outlined by Fuery at the beginning of this study.

While Gumbrecht compares medieval Christianity with its successor (Protestantism), Abram has made fruitful comparisons with one of its predecessors, Germanic paganism - or at least the image of Germanic paganism, such as it can be recovered from our scant sources. Abram ("Gylfaginning” IO, I2) has pointed out certain cosmological affinities between paganism as it appears in Snorri Sturluson's Gylfaginning and as it appears in the correspondence of Bishop Daniel of Winchester. An important notion in both these sources — both authored by Christians, of course - is that pagans are unable to construct a stable world-view based on absolute presences and absences. This is why Gylfi's famous question “Hvat var upphaf? Eða hversu hófsk? Eða hvat var ádr?” ("What was the beginning? Or how did things start? Or what was before?”; 9) is so troublesome. Both Daniel of Winchester and Snorri-speaking-through-Gylfi seek to apply a consistent (Christian) schema of concrete states to a (pagan) cosmology which is ill-defined and self-contradictory. Both interrogators force their "straw man" interrogées into admitting that they do not have plausible views on cosmogony, because they have not done much advanced thinking about the nature of presence. ${ }^{\mathrm{I} 2} \mathrm{~A}$ theologically orthodox Christian can answer the question "what was God doing before creation?" by turning the difficult question "in on itself" as per St. Augustine: si autem ante caelum et terram nullum erat tempus, cur quaeritur, quid tunc faciebas? non enim erat tunc, ubi non erat tempus ("if before heaven and earth were created there was no time, how can it be asked what You were doing 'then'? There was no 'then' when there was no 'time'”; 249). When Gylfi asks what Óðinn was doing before creation, the reply is: pá var hann með hrimpursum ("Then he was with the Ice Giants"; 9). The answer is opaque, because it gives only Óðinn's location rather than any reason why he dallied before supposedly creating the world. An opaque answer is given because Óðinn, unlike Augustine, has not developed a considered cosmology predicated on perfect absence before creation and real presence thereafter.

It hardly needs to be restated that Old Norse literature, like any Latin-script writing in the Middle Ages, is a product of medieval Christian culture. It is therefore unsurprising to find that most of the "churchier" works in Old Norse seem to subscribe to Gumbrecht's "real presence." Nonetheless, the natural tendency of the human mind to doubt, deconstruct and trouble any absolute value put before it means that a few Old Norse authors do betray traces of suspicion towards presence as a perfect state. The becoming-absent or becoming-present supernatural phenomena we have already discussed are themselves potent challenges to the "real presence" identified by Gumbrecht. But we can also observe doubt in perfect presence right where Gumbrecht found the very heart of the doctrine: transubstantiation. A theory first suggested by Gavin Langmuir (300-I), but frequently reiterated since, argues that the anti-Semitic motif of host desecration by Jews in medieval culture arises from repressed doubts over the possibility of Christ's supposedly indubitable presence during the eucharist. That is to say, the story of Jews attacking the host, blood pouring forth, and all the ensuing miracles would not have been necessary unless 
people were on some level uneasy with the dogmatic materialization of Christ's blood and flesh. To have the Jews, those seen as the ultimate skeptics of all Christianity's claims, acknowledge the doctrine themselves could operate as reassuring proof.

Intriguingly, such a story is known in Old Norse:

Enn sem peir hinu vondu hundar hafa med tekit, pa setiaz peir nidr i kranz hafandi medal sin einn bordskutil leggiandi pessa oblatam nidr 3 bordit, ok gera sua fordæmdan glæp, at peir stanga ok piacka oblatuna, sumir med knifun, sumier med suerdum, enn svmir med spiotum, par $æ$ it beinasta ofan i, sem peir sia, at Jesus er myndadr 3 krossinum. Her verdr frabær atb(u) rdr, puiat huar sem peir stinga i oblatuna, p3 sprettr heitr blodbogi upp i mot. Ok sem peir hinir vmildu gydingar lita pesse stormerki, verda peir 3kafliga hræddir ok ottafullir, skammaz nu miok sins illvirkis ok vilia sem skiotaz hylia med nockutu moti petta sitt nidingsverk, sua at peir gydinglig vtru verd eigi opinber. pui fara peir til ok grafua pessa obl3tuam langt i iord nidr ok ausa 3 moldu, rekandi ofan yfir ba hinu grænu torfu. (Maríu saga I059) ${ }^{\text {I3 }}$

And when those evil dogs had received it, they sit down in a circle around a little table, laying the host down on it, and do this condemnable deed: they stab and prick the host, some with knives, some with swords and even some with spears - always right precisely where they can see that Christ on the cross has been drawn. Now a wonderful event occurs, because wherever they stab into the host, then hot gushes of blood shoot out. And when these horrible Jews see this great sign they become terribly scared and afraid, and now they very much regret their evil deed and they want to hide their insulting behaviour as soon as possible, so that their Jewish faithlessness does not become apparent. Thus they go and bury this host deep in the ground and cover it with earth, placing green turf on top.

This legend conveys a number of messages. We note first certain features of ethnically oriented anti-Semitism: in this account the Jews are not just theologically problematic disbelievers, they are also downright sneaky, evil, people. There is obviously an affirmation of transubstantiation. But there is also a fierce defense of the integrity of presence. The Jews, who as we have seen are themselves a fascinating site of absence in Old Norse literature, do all they can to query and then even undo the perfect presence of Christ. In this metaphysical task they are defeated by Christianity:

Enn at lidnum vel tveim manudvm padan ifra, pa sa menn um nætr geisla standa alt upp til himins, ok par ofan yfir eina fagra stiorno. Foru menn sidan til ok grofu i iord nidr, par til er peir fundu eitt hardla vænt propiciatorivm, i hueriv sia hinn same guds likame var i geymdr med pvi blodi, er or stvngunum hafdi runnit. (Maríu saga I059)

And more than two months went by until one night people saw a beam shooting up into the sky, and atop of it a beautiful star, Then people went and dug down into the ground until they found a very handsome mercy seat in which the very same body of God was preserved together with the blood which had run out with all those stabs.

The message may feel a little neurotic in its labored self-affirmation. It is, nonetheless, a firm statement. Presence is a necessary article of Christian faith. By the same token, it can only ever be temporarily obscured; it ought not to be forthrightly questioned. Present may not be troubled, be incomplete, or be shrouded in doubt. That is the prerogative of absence alone. 


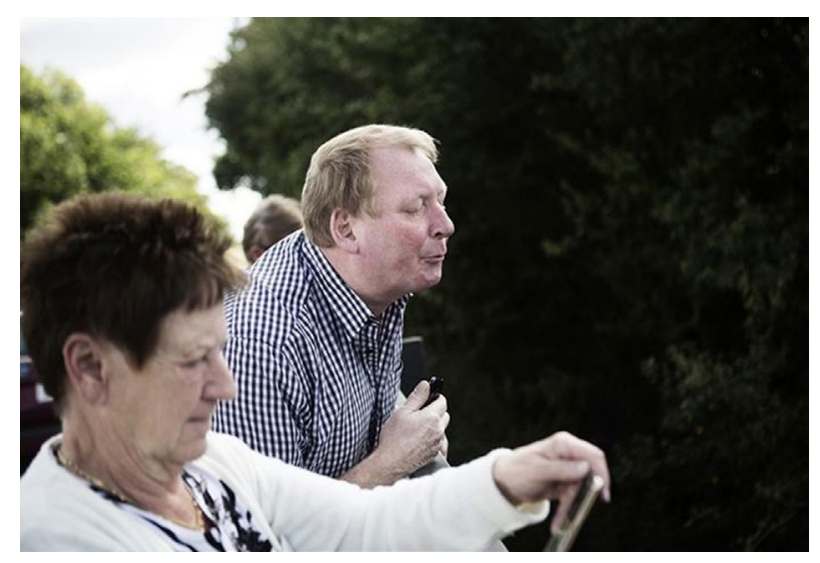

Figure 2 A Dane spits from a bridge over the E47 motorway at migrants below (the woman in the foreground is from the local Rødby branch of the Red Cross and has no relation to the man in question). Photo courtesy of: Sigrid Nygaard/Information.

\section{Conclusion}

I chose to apply this typology of absence to Old Norse literature because it is the field of human endeavor with which I am most familiar. However, in truth the theory of absence described here will apply in a variety of other contexts. Indeed, when formulating this article in my mind, I began by illustrating each gradation of absence with examples that had nothing to do with Old Norse, but were instead drawn from other medieval literatures, current events, and sometimes tales told to me by friends and acquaintances; for example, my first thought of a case of once-here-now-gone was England's Jewish population in the wake of the I 290 expulsion, a historical and literary case which has been ably studied in absence-minded terms by Krummel. For once-here-now-there I thought of the recent heartbreak of a friend.

The immense power which absence exerts on the psyche was particularly pressing as I came to make the final preparations for this article to go to print. It seems almost insulting for an Old Norse philologist in his ivory tower to comment on the dramatic exodus of human beings from Syria, but this movement does speak to the universal applicability of each species of absence, and of the emotional reactions those species provoke. For every home left empty, a real human life has become once-here-now-there. Many European countries, particularly to the West, behold the stream of newcomers as neverhere-now-there. Some British media demagogues look over the channel to La Jungle, a network of camps for migrants in Calais, France, from where a supposed invasion of Britain will take place. (e.g., Littlejohn). They seem to be spellbound by bodies which are - as yet - absent. Captivated by this species of absence, some under the influence of conservative, xenophobic media are seeing their streets with new eyes, imagining them becoming populated by threatening hordes in the immediate future. Others, perceiving precisely the same never-here-now-there absence, are instead imagining the landscape 
around them as havens for the sadly dispossessed. Such is the perspective of the tens of thousands who attended a rally in London to demand that the British government accept more refugees (Khomami and Johnston). Whether met with demeaning or welcoming responses, things that are not yet here can generate tremendous emotive force.

At the time of writing, the saddest and rawest recent example of the power of absence (to my mind) came from a case of becoming-present. A stream of migrants was passing along the E47 motorway, on their way through Denmark to Sweden. Sigrid Nygaard, a photojournalist from the Danish broadsheet Information, captured an image of a man on a bridge over the E47, spitting down on the human convoy below (Nygaard, see figure 2). The man is also reported to have recommended in no uncertain terms that the "Muslimsvin, skrid hjem til jeres land" - "Muslim pigs, go back to your own country" (Albrectsen). Like Kjartan in Eyrbyggja saga, furiously hammering the ghostly seal back into the ground, the Dane on that bridge seems terrified and disgusted by a phenomenon that had once been wholly absent to him, now beginning to emerge and fight its way to full presence. Like Kjartan, he wished he could drive that phenomenon away. Newcomers are so often liable to be perceived as things from another world that do not belong in our own. Unlike Kjartan, he failed. One can hardly look at Sigrid Nygaard's photograph and escape the meaning of Fowles' words, cited earlier: "it is in those moments when something has been actively rejected and aggressively avoided that we become especially aware of the flickering nature of absence and presence" (38).

The Lacanian nexus between absence and desire is not yet fully anatomized, and I admit that this little intervention has probably contributed little to that project. To expound exactly how each variety of absence generates desire necessitates a further, much larger study. The curious relationship of absence and desire may remain obscure, but we have examined some of the varying powers and forms absence assumes in Old Norse literature. Fuery writes of presence that it is "valued, held up, invested with power, and so can be said to have a pervasive quality. Presence, it appears, constructs, connects, holds together" (I). At the very least, I hope that what we have seen here is that all these things can really be said of absence too. From the daubing of the Icelandic landscape with the dye of ethnic identity to a disturbing deconstruction of the laws of physical reality, from broken-hearted warrior poets to grieving gods, from men with metal lovers to the yawning chasm before creation, we can see everywhere the effect of absence. Like the wandering Óðinn in the Christian world of the sagas, it may often lurk in obscurity, but we would act unwisely if we were to ignore its powers.

\section{Notes}

${ }^{\text {I }}$ For an edition of Ívar's account in the Old Danish in which it is now preserved, see: Det Gamle Grønlands Breskrivelse. An English translation is provided by Mathers (67-94).

${ }^{2}$ I am convinced by Einar Ól. Sveinsson's proposition (I9) that the more correct form would actually be "Kormakr", without the long á. However, I concede that Kormákr has remained the more recognizable

form, and that the length of the vowel has no effect on the present study.

${ }_{3}^{3}$ Christopher Abram and the anonymous reviewers at Exemplaria have helpfully pointed out to me that denoting Steingerðr as absent entirely depends on whose perspective one takes in the text. It is, after all, Kormákr who doesn't turn up on their wedding day. Reading Kormáks saga with Steingerðr in the 
subject position certainly empowers her, and would be a pleasing counterpoint to assessments such as those of Collingwood and Stefánsson: "[Kormákr] loves a fine lady, a spoiled child, who bewitches him, and jilts him, and jilts him again ... after years, he has her at his feet, and learns her heartlessness and worthlessness" (3). However, in this essay I largely comment on Kormáks saga with the titular character as the subject. As I argue elsewhere in this study, narrative voices in the sagas often seem to have robust strategies for restraining contrapuntal readings. There may well be something to be gained from exploring the androcentric world of the saga according to the subjective parameters its narrator appears to urge, while recognizing their inherent political problems.

${ }^{4}$ Kennings levelled to their base referents for the sake of clarity.

${ }^{5}$ All these examples are from Marín saga. See respectively: "Af líkneski várs herra" (IIO-II); "Af vndarligum atburd i pyveska landi" (I058-59); "Vor frv hialpadi iuda" $(963-65)$.

${ }^{6}$ It may well be that blámenn, serkir, and skrcelingar are what a Norse-speaker might have thought of as útangarðs. For more on the binary opposition between innangarðs "inside the garðr" and útangarðs "beyond the garðr", see Hastrup, esp. 65-66.

${ }^{7}$ Marteinn Helgi Sigurðsson has both surveyed and queried this tradition in two convincing studies (“'Perfectly Mamillary”, “pá váru hér”).

${ }^{8}$ For recent comment on this scene, see Støa.

${ }^{9}$ As an aside, we might contrast the position taken in Old Norse literature to such absence with another tradition from the Nordic Middle Ages, namely the Finnish Kalevala. In poem 37 the smith Ilmarinen is so aggrieved by the death of his wife that, like Tristram, he fashions a metal copy in her image. But unlike his Norse chivalric counterpart, Ilmarinen finds only hollow solace in his artificial companion, and when he shows her to Väinämöinen his response could not be more opposed to Kardín's enthusiasm: “Thrust your girl into the fire, forge her into all sorts of things, / or take her to Russia; take your image to Germany / for rich men to fight to marry, for noblemen to wage war to woo. / It is not fitting for my clan nor me myself / to woo a gold woman, to try to please one of silver" (259). Väinämöinen asserts that romancing a gynoid is something only a foreigner would do, perhaps hinting at a distaste for the motifs of imported European romance on the part of the poet.

${ }^{\text {Io }}$ Deleuze and Guattari were vocally dissatisfied with Lacan's insistence on the relationship between desire and lack: "Every time desire is betrayed, cursed, uprooted from its field of immanence, a priest is behind it. The priest cast the triple curse on desire: the negative law, the extrinsic rule, and the transcendent ideal. Facing north, the priest said, Desire is lack (how could it not lack what it desires?). The priest carried out the first sacrifice, named castration, and all the men and women of the north lined up behind him, crying in cadence, 'Lack, lack, it's the common law'" (Deleuze and Guattari I7I). Regrettably, space does not permit me to approach the lack-desire complex in the present study.

${ }^{11}$ For Hans Ulrich Gumbrecht and other theorists of absence, the body is the most important site of presence. At least one Old Norse voice was also keenly aware of the body as a site of presence - consider the Elucidarius explaining God's omnipresence despite His apparent absence from the visible world: Iengom stap segesc hann vesa. Puiat hann es ólicamlegr oc ma eige licamlegr stapr halda á Gope (4): "He is said to be in no place because he is non-physical [lit. "non-bodily"] and no physical place may contain God.” The implication is that for all other, non-divine beings, possession of a likamr (body) is integral to the means of producing presence.

${ }^{12}$ As Abram notes, Rory McTurk (3-I8) provides a starting point for the broader conversation about whether Gylfi is wholly duped by the pagan gods, or remains skeptical and thus destabilizes Óðinn's profane proselytism with his questions.

${ }^{13}$ Incidentally, this seems to be a description of the case of supposed host desecration from Güstrow in I330. The legend is set in a place called Gvdstru and relates the building of a church there which would appear to be the Kapelle des heiligen Bluts. This could be a useful terminus post quem for the dating of the second hand in Perg. Cod. II $4^{\text {to }}$.

\section{Works cited}

Abram, Christopher. "Gylfaginning and Early Medieval Conversion Theory.” Saga-Book, 33, 5-24.

—. "Snorri's Invention of Hermóðr's helreið." The Fantastic in Old Norse / Icelandic Literature. Sagas and the British Isles: Preprint Papers of The I3th International Saga Conference. Vol. I. Ed. John McKinnell, David Ashurst, and Donata Kick. Durham: The Centre for Medieval and Renaissance Studies, 2006. 22-3I.

Albrectsen, Nikolaj. "Lili var med på billedet: Hængt ud som hustru til spyttende mand." TV2 Nyhederne 8 Sept. 20I5. Web. I5 Sept. 20I5.

Arendt, Hannah. Eichmann in Jerusalem: A Report on the Banality of Evil. London: Penguin Books, 2006.

Augustine. Confessionum. Libri Tredecim. Ed. P. Knöll. Leipzig: B. G. Teubner, I898.

Barthes, Roland. A Lover's Discourse: Fragments. Trans. Richard Howard. London: Penguin, I999. 
Bárðarson, Ívar. Det Gamle Grønlands Beskrivelse. Ed. Finnur Jónsson. Copenhagen: Levin \& Munksgaards Forlag, I930.

Bille, Mikkel, et al., eds. An Anthropology of Absence: Materializations of Transcendence and Loss. New York, NY: Springer, 2010.

Árna saga =Biskupa Sögur. Vol. 3. Ed. Guðrún Ása Grímsdóttir. Reykjavík: Hið Íslenzka Fornritafélag, 2008.

Cleasby, Richard \& Vigfússon, Guðbrandur. An Icelandic-English Dictionary. Oxford: Clarendon P., I874.

Clover, Carol J. \& Lindow, John (Eds.). Old Norse-Icelandic Literature: A Critical Guide. Ithaca: Cornell UP, I985.

Cole, Richard. The Jew Who Wasn't There: Studies on Jews and their Absence in Old Norse Literature. Diss: Harvard University, 20I5.

. Racial Thinking in Old Norse Literature: The Case of the Blámaðr. Saga-Book, 39 (2015): 5-24.

Collingwood, W. G., and Jón Stefánsson. "Introduction." The Life and Death of Cormac the Skald. Ulverston: W. M. Homes, I902.

Deleuze, Gilles. The Logic of Sense. Trans. Mark Lester with Charles Stivale. Ed. Constantin V. Boundas. London: Continuum, 20II.

Deleuze, Gilles \& Guattari, Félix. A Thousand Plateaus. Capitalism and Schizophrenia. Trans. Brian Massumi. London: Continuum, 2004

Edda $=$ Snorri Sturluson. Edda: Prologue and Gylfaginning. Ed. Anthony Faulkes. London: Viking Society for Northern Research, 2005 .

Einar Ól. Sveinsson. "Kormakr the Poet and his verses." Saga-Book I7 (I966): 44-5I.

Elucidarius: The Old Norse. Ed. and trans. Evelyn Scherabon Firchow. Columbia, SC: Camden House, I992.

Eyrbyggja Saga. Brands Páttr Orva. Eiríks Saga Rauða. Grœnlendinga Saga. Grœnlendinga Páttr. Ed. Einar Ól. Sveinsson and Matthías Pórðarson. Íslenzk Fornrit 4. Reykjavík: Hið Íslenzka fornritafélag, I935.

Gǫngu-Hrólfs saga $=$ Fornaldarsögur Norðrlanda. Vol. 3. Ed. Valdimar Ásmundarson. Reykjavík: Sigurður Kristjánsson, I889.

Fowles, Severin. "People Without Things." An Anthropology of Absence: Materializations of Transcendence and Loss. Ed. Mikkel Bille et al. New York, NY: Springer, 2010. 23-4I.

Fritzner, Johan. Ordbog over Det gamle norske Sprog, Vol. I. Oslo: Tryggve Juul Møller Forlag, I954.

Fuery, Patrick. The Theory of Absence: Subjectivity, Signification, and Desire. London: Greenwood P., I995.

Glauser, Jürg. "Draugr and Aptrganga." Medieval Scandinavia: An Encyclopedia. Ed. Philip Pulsiano and Kirsten Wolf. London: Garland, I993.

Gumbrecht, Hans Ulrich. Production of Presence: What Meaning Cannot Convey. Stanford: Stanford UP, 2004.

Gumbrecht, Hans Ulrich. The Powers of Philology: Dynamics of Textual Scholarship. Chicago, IL: U of Illinois P, 2003. Guta Saga: The History of the Gotlanders. Ed. Christine Peel. London: Viking Society for Northern Research, I999. Hastrup, Kirsen. "Cosmology and Society in Medieval Iceland. A Social Anthropological Perspective on World-view". Ethnologia Scandinavica II (I98I): 64-78.

Historia Norwegie. Ed. Inger Ekrem and Lars Boje Mortensen. Trans. Peter Fisher. Copenhagen: Museum Tusculanum Press, 2003.

Gottskálks Annall = Islandske Annaler indtil I 578. Ed. Gustav Storm. Christiania: Grøndahl \& Søns Bogtrykkeri, I888.

Íslendingabók, Landnámabók. Vol. I. Ed. Jakob Benediktsson. Íslenzk Fornrit I. Reykjavík: Hið Íslenzka Fornritafélag, I968.

Ármann Jakobsson. The Fearless Vampire Killers: A Note about the Icelandic Draugr and Demonic Contamination in Grettis saga. Folklore, I20, 3 (2009): 307-I6.

Lindow, John, et al., eds. Structure and Meaning in Old Norse Literature: New Approaches to Textual Analysis and Literary Criticism. Odense: UP of Southern Denmark, I986.

Tristrams saga ok Ísǫndar = Kalinke, Marianne, ed. Norse Romance: Volume I. The Tristan Legend . Cambridge: D. S. Brewer, I999.

The Kalevala or Poems of the Kalevala District. Comp. Elias Lönnrot. Trans. Francis Peabody Magoun Jr. Cambridge, MA: Harvard University Press, 1963.

Khomami, Nadi, and Chris Johnston. "Thousands Join Solidarity with Refugees Rally in London.” The Guardian I2 Sept. 2015. Web. I5 Sept. 2015.

Krummel, Miriamne Ara. Crafting Jewishness in Medieval England: Legally Absent, Virtually Present. New York, NY: Palgrave Macmillan, 20II.

Langmuir, Gavin. History, Religion and Antisemitism. Berkeley: U of California Press., I993.

Laxdœela saga. Halldórs Peettir Snorrasonar. Stúfs Páttr. Ed. Einar Ól. Sveinsson. Íslenzk Fornrit 5. Reykjavík: Hið Íslenzka Fornritafélag, I934.

Littlejohn, Richard. “Once Again, We’ve Been Done Up Like a Hareng-Fume (That's French for Kipper).” Daily Mail 2I Aug. 2015. Web. I5 Sept. 20I5. 
Lönnroth, Lars. "Structuralist Approaches to Saga Literature." Learning and Understanding in the Old Norse World: Essays in Honour of Margaret Clunies Ross. Ed. Judy Quinn, et al. Turnhout: Brepols, 2007. 63-73.

Mariu Saga. Legender om Jomfru Maria og hendes jertegn, efter gamle haandskrifter. Ed. C. R. Unger. Christiania: Brögger \& Christie, I87I.

Marteinn Helgi Sigurðsson. "Perfectly Mamillary’: On Breasts, Nipples and Teats in West Norse Toponymy.” Norrcen nöfn-Nöfná Norðurlöndum: Hefðir og Endurnýjun. Ed. Guðrún Kvaran, et al. Uppsala: Norna-Förlaget, 2008: $297-307$.

Marteinn Helgi Sigurðsson. "Pá váru hér menn kristnir ....” 38 Vöplur Bakaðar og Bornar fram Guðrúnu. Ed. Guðvarður Már Gunnlaugsson, et al. Reykjavík: Menningar- og minningarsjóður Mette Magnussen, 2009: 70-73.

Mathers, Derek. A Fourteenth Century Description of Greenland. Saga-Book, 33 (2009): 67-94.

McTurk, Rory. Fooling Gylfi: Who Tricks Who? Alvíssmál, 3 (I994): 3-I8.

Mills, Kristen. “Male Weeping in Snorri's Account of Baldr's Death, Kings' Sagas, and Gesta Danorum.” Journal of English and Germanic Philology, I33, 4 (2014): 472-96.

Nygaard, Sigrid. “Skræmmekampagnen virker.” Information 8 Sept. 20I 5 . Web. I5 Sept. 2015.

O'Connor, Ralph. "History or Fiction? Truth-claims and Defensive Narrators in Icelandic Romance-sagas." Mediaeval Scandinavia, I5 (2005): IOI-69.

The Oxford Dictionary of English Etymology. Ed. C. T. Onions. Oxford: Clarendon P, I996.

Schjødt, Jens Peter. Initiation Between Two Worlds: Structure and Symbolism in Pre-Christian Scandinavian Religion. Trans. Victor Hansen. Odense: UP of Southern Denmark, 2008.

Shafer, John. Saga-Accounts of Norse Far-Travellers. PhD Diss: University of Durham, 2009.

Socor, Barbara J. Conceiving the Self: Presence and Absence in Psychoanalytic Theory. Madison, WI: International Universities Press, I997.

Støa, Heidi. "The Lover and the Statue: Idolatrous Love in Tristams saga ok Ísöndar” Scandinavian Studies, 87, I (2015): I29-46.

Vatnsdœela saga. Hallfreðar saga. Kormáks saga. Hrómundar Páttr Halta. Hrafns Páttr Guðrúnarsonar. Ed. Einar Ól. Sveinsson. Íslenzk Fornrit 8. Reykjavík: Hið Íslenzka Fornritafélag, I939.

Ynglinga Saga = Snorri Sturluson. Heimskringla. Vol. I. Ed. Bjarni Aðalbjarnarson. Íslenzk Fornrit 26 Reykjavík: Hið Íslenzka Fornritafélag, I96r.

Young, James. E. The Texture of Memory: Holocaust Memorials and Meaning. Bloomington: Indiana UP, I993.

\title{
Note on contributor
}

\author{
Richard Cole is a Postdoctoral Teaching Fellow in Old Norse at Harvard University. \\ Correspondence to: Richard Cole. Email: richardcole@alumni.harvard.edu
}

